\title{
SARS-CoV-2 and Nervous System - Neurological Manifestations in Patients With COVID-19: A Systematic Review
}

\author{
Luiz Severo Bem Junior ${ }^{\mathrm{a}, \mathrm{b}, \mathrm{f}}$, Pedro Lukas do Rego Aquino ${ }^{\mathrm{c}}$, Nicollas Nunes Rabelo, \\ Maria Amellia do Rego Aquino ${ }^{\mathrm{e}}$, Ana Cristina Veiga Silva ${ }^{\mathrm{a}}$, \\ Rita de Cassia Ferreira Valenca Mota ${ }^{a}$, Hildo Rocha Cirne de Azevedo Filho ${ }^{\text {a }}$
}

\begin{abstract}
Coronavirus $(\mathrm{CoV})$ is a virus infectious disease with a considerable spectrum of clinical presentations. Symptoms ranged from asymptomatic infection to severe pneumonia that may lead to severe acute respiratory syndrome coronavirus 2 (SARS-CoV-2) and several clinical complications. Neurologic symptoms related to $\mathrm{CoV}$ have been described recently in the literature. The relationship between SARS-CoV-2 and the central nervous system (CNS) is still not clear. This review aimed to reveal the current knowledge regarding CNS manifestation in SARS-CoV-2. A systematic literature review was carried out to identify the particularities of coronavirus disease 2019 (COVID-19) in patients with CNS involvement, using the PubMed database between January 1, 2020 and April 30, 2020. Conference papers, reviews, published letters, editorials, studies in pregnant women and children, and studies only reporting on a specific factor were excluded. An initial search included as many as 83 articles. Out of the 83 screened articles, 32 were selected for full-text review. Sixteen studies were excluded because they did not analyze nervous system involvement in SARS-CoV-2 infection. Thus, 16 papers were included in this review. There were three retrospective studies and 13 case reports/series of cases. Data from the current literature reveal that patients who suffer from a severe illness have more CNS involvement, neurological symptoms (i.e., dizziness, headache) and an association with strokes. The severe patients had higher D-dimer and C-reactive protein levels than non-severe patients and presented multiple organ
\end{abstract}

Manuscript submitted May 30, 2020, accepted June 10, 2020

Published online June 30, 2020

${ }^{a}$ Neuroscience Post-Graduate Program, Federal University of Pernambuco, Recife, Brazil

bNeurology Department, Faculty of Medical Science, UNIFACISA, Campina Grande, Brazil

${ }^{c}$ Faculty of Medical Science, University of Pernambuco, Recife, Brazil dNeurosurgery Department, UniAtenas University Center, Paracatu, Brazil ${ }^{\mathrm{e} H o s p i t a l}$ das Clinicas, Federal University of Pernambuco, Recife, Brazil ${ }^{\mathrm{f} C}$ Corresponding Author: Luiz Severo Bem Junior, Neuroscience Post-Graduate Program, Federal University of Pernambuco, Av. Prof. Moraes Rego, 1235 Cidade Universitaria, Recife - PE, 50670-901, Brazil.

Email: luizseverobemjunior@gmail.com

doi: https://doi.org/10.14740/jnr602 involvement, such as serious liver, kidney and muscle damage.

Keywords: Neurologic manifestations; COVID-19; Nervous system; SARS-CoV-2; Stroke

\section{Introduction}

Coronaviruses $(\mathrm{CoVs})$ cause enteric and respiratory diseases in humans and animals and are enveloped non-segmented positive-sense RNA viruses [1]. Severe acute respiratory syndrome coronavirus (SARS-CoV) and Middle East respiratory syndrome coronavirus (MERS-CoV) had already been known for physicians $[2,3]$. However, another highly pathogenic coronavirus named SARS-CoV-2 emerged in December 2019 in China and rapidly reached the world.

This virus shares a highly homological sequence with SARS-CoV and MERS-CoV [2, 3]. The infection of SARSCoV-2 has been reported in the brains of patients and experimental animals. However, the relationship between SARS$\mathrm{CoV}-2$ and the central nervous system (CNS) is still not clear [2]. This review aimed to reveal the current knowledge regarding CNS manifestation in SARS-CoV-2.

\section{Methods}

To review the particularities of coronavirus disease 2019 (COVID-19) in patients with CNS involvement, an electronic search of the literature was conducted in the PubMed database between January 1, 2020 and April 30, 2020. Data extraction and the evaluation of literature quality were conducted independently by two investigators. Microsoft Excel database was used to record all available information. Any disagreement was resolved by another investigator. The following keywords with Boolean operators were used "COVID-19 AND CNS" or "COVID-19 AND neurologic" or "COVID-19 AND stroke". A total of 74 articles were extracted. Moreover, we handsearched (manual search) and included nine more articles. We only selected case reports, series of cases, retrospective studies 


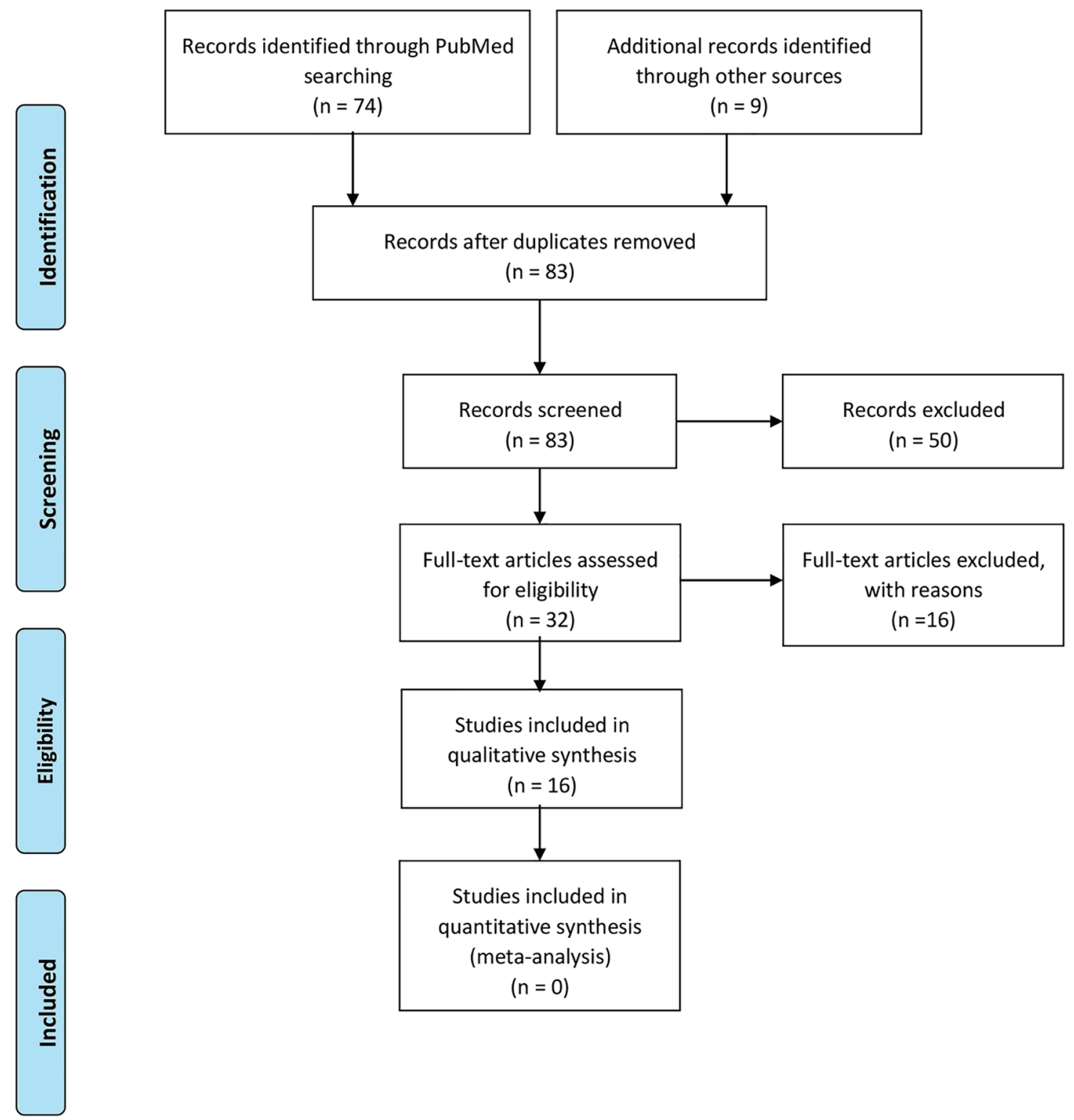

Figure 1. PRISMA flow diagram.

and prospective studies. We included articles in all languages. Conference papers, reviews, published letters, editorials, studies in pregnant women and children, and studies only reporting on a specific factor were excluded. Our work is summarized in the PRISMA diagram below (Fig. 1).

Case reports and series of cases were divided into two groups: the acute neurological manifestation of COVID-19 and the later neurological manifestation of COVID-19. Besides, acute neurological manifestation of COVID-19 was divided into two subgroups: vascular disorder and inflammatory disorder.

\section{Results}

An initial search included as many as 83 articles. Out of the 83 screened articles, 32 were selected for full-text review. Sixteen studies were excluded because they did not analyze nervous system involvement in SARS-CoV-2 infection. Thus, 16 papers were included in this review. There were three retrospective studies and 13 case reports/series of cases.

\section{Case reports and series of cases}

In a total of 13 case reports/series of cases that analyzed nervous system involvement, 26 cases were reported.

In the group of patients who developed acute vascular neurological manifestation, 19 patients were reported. The average age was 54.2 years and the more frequent gender was male $(57.8 \%)$. Clinical manifestations included general symp- 
Table 1. Acute Vascular Neurological Manifestation in Patients With SARV-CoV-2 Infection

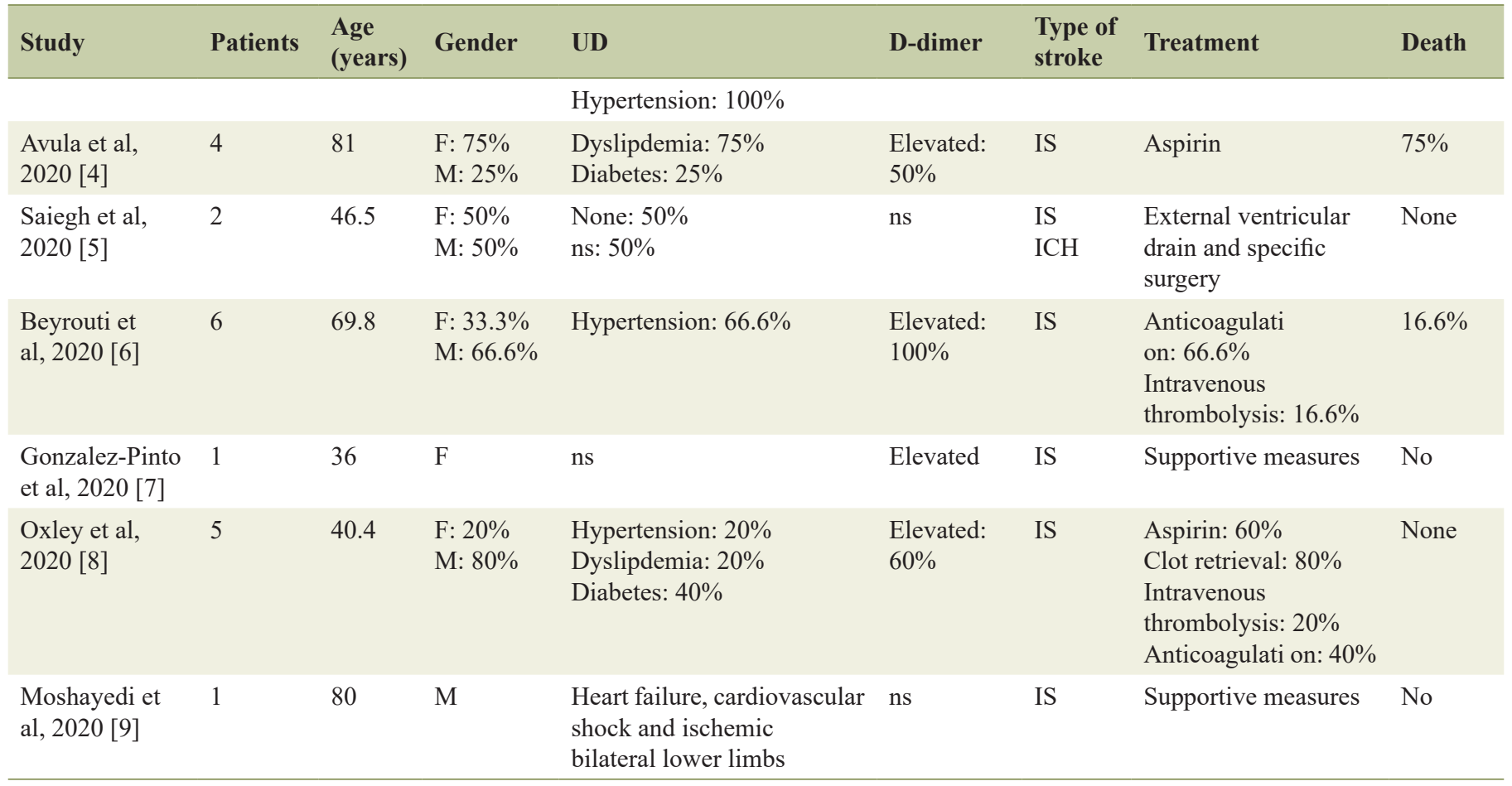

Median; F: female; M: male; UD: underlying disorders; IS: ischemic stroke; ICH: intracerebral hemorrhage; ns: not specified.

toms (fever, cough, fatigue, etc.) and neurological symptoms and motor deficit. The main underlying disease observed was hypertension $(47.3 \%)$, followed by diabetes $(31.5 \%)$ and hypercholesterolemia (26.3\%). In blood investigation, 12 of 19 patients $(63 \%)$ had higher D-dimer levels and six of 19 patients $(31.5 \%)$ had higher C-reactive protein (CRP) levels. Abnormal chest image was reported in 10 of 19 patients $(52.6 \%)$. In $94.7 \%$ of the cases, ischemic stroke was diagnosed and $11 \%$ of the patients developed hemorrhage transformation. Intracerebral hemorrhage was observed in only one case $(5.2 \%)$. The mortality rate in patients with acute vascular neurologic manifestation was $21 \%$. Table 1 complements all of this informa- tion [4-9].

In the group of patients who developed an acute inflammatory neurological disorder, only three cases were observed, including meningitis/encephalitis, necrotizing hemorrhagic encephalopathy and demyelinating lesions. The average age in this group was 42.6 years and female was the more common gender. Abnormal brain image was observed in all cases and abnormal chest image was reported in two of three cases $(66.6 \%)$. None death was reported. Table 2 summarizes and complements all of this information [10-12].

In the group of patients who developed later neurological manifestation, four cases were reported. All of the cases re-

Table 2. Acute Inflammatory Neurological Manifestation in Patients With SARV-CoV-2 Infection

\begin{tabular}{|c|c|c|c|c|c|c|}
\hline Study & $\begin{array}{l}\text { Age } \\
\text { (gender) }\end{array}$ & Symptoms & BI & $\begin{array}{l}\text { Type of } \\
\text { inflamation }\end{array}$ & Treatment & Outcome \\
\hline $\begin{array}{l}\text { Moriguchi et } \\
\text { al, } 2020[10]\end{array}$ & $\begin{array}{l}24 \text { years } \\
(\mathrm{M})\end{array}$ & $\begin{array}{l}\text { Headache, } \\
\text { fatigue, fever and } \\
\text { consciousness } \\
\text { disturbance }\end{array}$ & $\begin{array}{l}\text { Elevated: white cell count, } \\
\text { neutrophil dominant } \\
\text { Decreased: lymphocytes, } \\
\text { increased C-reactive protein }\end{array}$ & $\begin{array}{l}\text { Meningitis/ } \\
\text { encephalitis }\end{array}$ & $\begin{array}{l}\text { Intravenous ceftriaxone, } \\
\text { vancomycin, acyclovir } \\
\text { and corticosteroids }\end{array}$ & ns \\
\hline $\begin{array}{l}\text { Poyiadji et } \\
\text { al, } 2020[11]\end{array}$ & $\begin{array}{l}50 \text { years } \\
(\mathrm{F})\end{array}$ & $\begin{array}{l}\text { Cough, fever } \\
\text { and altered } \\
\text { mental status }\end{array}$ & ns & $\begin{array}{l}\text { Necrotizing } \\
\text { hemorrhagic } \\
\text { encephalopathy }\end{array}$ & $\begin{array}{l}\text { Intravenous } \\
\text { immunoglobulin }\end{array}$ & ns \\
\hline $\begin{array}{l}\text { Zanin et al, } \\
2020[12]\end{array}$ & $\begin{array}{l}54 \text { years } \\
(\mathrm{M})\end{array}$ & $\begin{array}{l}\text { Anosmia, ageusia } \\
\text { and loss of } \\
\text { consciousness }\end{array}$ & $\begin{array}{l}\text { Elevated: C-reactive } \\
\text { protein and fibrinogen } \\
\text { Decreased: lymphocytes }\end{array}$ & $\begin{array}{l}\text { Demyelinating } \\
\text { lesions (brain } \\
\text { and spine) }\end{array}$ & $\begin{array}{l}\text { Antiretroviral, } \\
\text { hydroxychloroquine, } \\
\text { antiepileptic and } \\
\text { corticosteroids }\end{array}$ & Discharged \\
\hline
\end{tabular}

M: male; F: female; BI: blood investigation; ns: not specified. 
Table 3. Late Neurological Manifestation in Patients With SARV-CoV-2 Infection

\begin{tabular}{|c|c|c|c|c|c|c|}
\hline Study & $\begin{array}{l}\text { Age } \\
\text { (gender) }\end{array}$ & UD & $\begin{array}{l}\text { Symptoms (on- } \\
\text { set days) }\end{array}$ & Diagnosis & Treatment & Outcome \\
\hline $\begin{array}{l}\text { Alberti et al, } \\
2020[13]\end{array}$ & 71 years $(F)$ & $\begin{array}{l}\text { Hypertension, } \\
\text { abdominal aortic } \\
\text { aneurysm and } \\
\text { lung cancer }\end{array}$ & $\begin{array}{l}\text { Paresthesia, } \\
\text { weakness, and flaccid } \\
\text { tetraparesis (3) }\end{array}$ & $\begin{array}{l}\text { Guillain-Barr } \\
\text { syndrome }\end{array}$ & $\begin{array}{l}\text { Intravenous immunoglobulin, } \\
\text { antiviral and hydroxychloroquine }\end{array}$ & Death \\
\hline $\begin{array}{l}\text { Virani et al, } \\
2020[14]\end{array}$ & 54 years $(\mathrm{M})$ & ns & $\begin{array}{l}\text { Complaints of } \\
\text { numbness and } \\
\text { weakness (2) }\end{array}$ & $\begin{array}{l}\text { Guillain-Barr } \\
\text { syndrome }\end{array}$ & $\begin{array}{l}\text { Intravenous immunoglobulin, } \\
\text { hydroxychloroquine }\end{array}$ & Discharged \\
\hline $\begin{array}{l}\text { Sedaghat et } \\
\text { al, } 2020[15]\end{array}$ & 65 years $(\mathrm{M})$ & Diabetes & $\begin{array}{l}\text { Acute progressive } \\
\text { symmetric ascending } \\
\text { quadriparesis (5) }\end{array}$ & $\begin{array}{l}\text { Guillain-Barr } \\
\text { syndrome }\end{array}$ & $\begin{array}{l}\text { Intravenous Immunoglobulin, } \\
\text { hydroxychloroquine, lopinavir/ } \\
\text { ritonavir and azithromycin }\end{array}$ & Discharged \\
\hline $\begin{array}{l}\text { Zhao et al } \\
2020[16]\end{array}$ & 69 years $(\mathrm{F})$ & ns & $\begin{array}{l}\text { Acute weakness } \\
\text { in both legs and } \\
\text { severe fatigue (1) }\end{array}$ & $\begin{array}{l}\text { Guillain-Barr } \\
\text { syndrome }\end{array}$ & $\begin{array}{l}\text { Intravenous immunoglobulin, } \\
\text { arbidol, lopinavir and ritonavir }\end{array}$ & Discharged \\
\hline
\end{tabular}

M: male; F: female; UD: underlying disorders; ns: not specified.

ported Guillain-Barr syndrome. The average age in this group was 64.75 years with the same proportion between male and female gender. The chest image was abnormal in all patients. Intravenous immunoglobulin was instituted in all cases and hydroxychloroquine was used in three of four patients $(75 \%)$. One patient died and three patients were discharged. All of this information is summarized in Table 3 [13-16].

\section{Retrospective studies}

Mao et al observed CNS manifestation in $25 \%$ of all patients included in their study $(\mathrm{N}=214)$ and the most common symptom was dizziness (17\%), followed by headache (13\%) [17]. Patients who had CNS symptoms presented lower lymphocyte, platelet counts and higher blood urea nitrogen levels compared with those without CNS symptoms [17]. Ischemic stroke was observed in $7.5 \%$ of all patients and cerebral hemorrhage was observed in $1.9 \%$ [17]. This study did not specify age and gender in patients with cerebrovascular disease (CVD), an average of durations from the first symptoms of SARS-CoV-2 infection to CVD and underlying disorders in patients with CVD [17]. This study concluded that CNS manifestation carries a poor prognosis in COVID-19 [17].

In Li et al's study with 221 patients, the age ranged from 57 to 91 years and the male gender was more common to develop CVD [3]. The prevalent of CVD in all patients studied was $6 \%$ and hypertension and diabetes were the most common underlying disorders in patients with CVD [3]. The average of durations from the first symptoms of SARS-CoV-2 infection to CVD was 10 days in this study [3]. Patients who developed CVD had high white blood cells, neutrophil counts and CRP levels [3]. Lower lymphocyte counts were found. Eleven of 221 patients $(5 \%)$ developed ischemic stroke, $0.5 \%$ cerebral venous sinus thrombosis and $0.5 \%$ cerebral hemorrhage [3]. This study concluded that older patients with risk factors can be more favorable to develop CVD and CVD is an important negative prognostic factor [3].
In Lodigiani et al's study, CVD complication age ranged from 57 to 82 years [18]. In concordance with Li et al, the male gender was more prevalent $(66.7 \%)$ [18]. Nine of 362 closed cases (2.5\%) developed CVD [18]. All of the patients who developed CVD presented ischemic stroke [18]. In blood investigation, it was observed that non-survivors patients have evaluated rapidly with increasing high D-dimer levels, over $249 \mathrm{ng} / \mathrm{mL}$, 9 - 10 days after the first symptom [18]. The study concluded that high D-dimer levels may indicate poor prognosis.

Table 4 summarizes all of these retrospective studies discussed $[3,17,18]$.

\section{Discussion}

\section{Physiopathology}

The complete genome of SARS-CoV-2 is a 29.903 bp singlestranded RNA (ss-RNA) CoV. Thus, the virus causing COVID-19 is a SARS-like CoV that had previously been reported in bats in China [1, 19].

CoVs have been shown to develop neuroinvasion, infect and induce neurological disease (neurovirulence) in animal models [2]. The entry of SARS-CoV and MERS-CoV on human host cells is mainly via dipeptidyl peptidase 4 (DPP4) [2, 3]. However, studies demonstrated SARS-CoV-2 enters into human host cells from different receptors. The main receptor of SARS-CoV-2 entrance is the cellular receptor angiotensinconverting enzyme 2 (ACE2), which is expressed in many tissues of the body such as human airway epithelia, lung parenchyma and vascular endothelia [20]. The brain has been reported to express ACE2 receptors that have been detected over neurons and glial cells, which explain the neurotropism of SARS-CoV-2 [21].

The COVID-19 mRNA encoded several proteins and the virus gets used to a spike protein $\mathrm{S} 1$ that enables the attachment of the virion to the cell membrane by interacting with 
Table 4. Review of Retrospective Studies on Neurological Manifestations in Patients With COVID-19

\begin{tabular}{|c|c|c|c|c|c|c|}
\hline Study & $\begin{array}{l}\text { Patients with } \\
\text { neurological } \\
\text { symptoms }\end{array}$ & Age & BI & $\begin{array}{l}\text { Neurological } \\
\text { complication }\end{array}$ & Outcome & Limitation \\
\hline $\begin{array}{l}\text { Mao et al, } \\
2020[17]\end{array}$ & 53 & ns & $\begin{array}{l}\text { Lower lymphocyte, } \\
\text { platelet counts and } \\
\text { higher blood urea } \\
\text { nitrogen levels }\end{array}$ & $\begin{array}{l}\text { Ischemic stroke } \\
7.5 \% \text { and cerebral } \\
\text { hemorrhage } 1.9 \%\end{array}$ & ns & $\begin{array}{l}\text { Single-center study, all data } \\
\text { were abstracted from the } \\
\text { electronic medical records; } \\
\text { no EEG study; no clear } \\
\text { definition of symptoms; and } \\
\text { no outcome information }\end{array}$ \\
\hline $\begin{array}{l}\text { Li et al, } \\
2020[3]\end{array}$ & 13 & $\begin{array}{l}\text { Age ranged from } \\
32 \text { to } 91 \text { years }\end{array}$ & $\begin{array}{l}\text { High white blood cell, } \\
\text { neutrophil counts and } \\
\text { C-reactive protein } \\
\text { levels; and lower } \\
\text { lymphocyte counts }\end{array}$ & $\begin{array}{l}\text { Ischemic stroke } \\
(84 \%) \text {, cerebral } \\
\text { venous sinus } \\
\text { thrombosis }(7.6) \\
\text { and cerebral } \\
\text { hemorrhage } \\
(7.6 \%)\end{array}$ & $\begin{array}{l}\text { Survive } \\
\text { rate } \\
(61.5 \%) \\
\text { death rate } \\
(38.4 \%)\end{array}$ & $\begin{array}{l}\text { Single-center study; no EEG } \\
\text { study; no clear definition } \\
\text { of symptoms; and no } \\
\text { outcome information }\end{array}$ \\
\hline $\begin{array}{l}\text { Lodigiani et } \\
\text { al, } 2020[18]\end{array}$ & 9 & $\begin{array}{l}\text { Age ranged } \\
\text { from } 57 \text { to } 82\end{array}$ & $\begin{array}{l}\text { High D-dimer levels } \\
(>249 \mathrm{ng} / \mathrm{mL})\end{array}$ & Ischemic stroke & $\begin{array}{l}\text { Survive } \\
\text { rate } \\
(77.7 \%) ; \\
\text { death rate } \\
(22.2 \% \%)\end{array}$ & $\begin{array}{l}\text { Single-center study, they } \\
\text { could not confirm whether } \\
\text { thromboembolic events } \\
\text { contributed substantially to } \\
\text { such a dramatic mortality } \\
\text { and no autopsies were } \\
\text { routinely performed }\end{array}$ \\
\hline
\end{tabular}

BI: blood investigation; ns: not specified; EEG: electroencephalography.

the ACE2 receptor $[21,22]$. In a study, it was shown that the ACE2 binding affinity of the SARS-CoV-2 spike protein ectodomain was 10 - to 20 -fold higher than that of the SARSCoV-2 spike protein [22].

The exact pathway by which SARS-CoV-2 and MERS$\mathrm{CoV}$ enter the CNS is still not clear. The main pathway is associated with hematogenous dissemination of infected leukocytes through compromised endothelial cells of the bloodbrain barrier $[3,20]$. Nerve dissemination is possible by the polarization of neurons, and this transport can be retrograde or antegrade $[3,20]$. Dinein and kinesin proteins aid in the process and may be the target of viruses [23].

In the study of $\mathrm{Gu}$ et al, eight autopsies were detected in SARS victims with neuronal histopathological alterations in the hypothalamus and cortex [24]. In the case of SARS-CoV-2, retrograde propagation along the olfactory tract may explain anosmia in some cases $[3,20]$. The initial colonization of the brain at the olfactory bulbs before the spreading proceeds to the highly susceptible regions, such as the piriform cortex and other regions associated with olfaction, and then globally through the CNS. The initial olfactory pathway begins in bipolar cells located in the olfactory epithelium and axons and dendrites extend to the olfactory bulb [25]. Over there, the synapses happen with the cells present in this structure. After this, the cranial pair is directed towards the olfactory nucleus present in the pyriform cortex [25]. The use of this nerve route was observed by other CoVs in animal models and can explain similarly the SARS-CoV-2 pathway $[21,25]$.

When the virus found neuronal tissues, its interaction with ACE2 receptors can initiate a cycle of viral budding ac- companied by neuronal damage as has been seen with cases of SARS-CoV-2 [21, 26]. Also, the endothelial ruptures in cerebral capillaries can bleed before neuronal damage happen $[5,26]$. It can explain intracerebral hemorrhage in COVID-19 patients that have already been reported in the literature [5]. Moreover, an altered sense of smell or hyposmia in an early stage COVID-19 patient should be investigated for CNS involvement $[27,28]$. Figure 2 summarizes the nervous system involvement in SARS-CoV-2 infection.

Epstein-Barr virus can be similar to SARS-CoV-2 in CNS physiopathology involvement. In a study in mouse models, the increased disease severity in Epstein-Barr infection was associated with enhanced leukocyte entry into the CNS with greater numbers of both $\mathrm{CD} 8^{+} \mathrm{T}$ cells and virus-specific $\mathrm{CD} 8^{+} \mathrm{T}$ cells than wild-type mice [29]. Thus, this development mechanism in patients with severe disease in Epstein-Barr infection can be similar to SARS-CoV-2 infection.

\section{Clinical features in COVID-19 related to neurological manifestation}

Respiratory involvement is the most common in patients with COVID-19 infection; however, there are reports of neurological manifestations $[1,2]$. The median time from the first symptom to dyspnea in patients with COVID-19 was 5.0 days, to hospital admission was 7.0 days, and to the intensive care was 8.0 days $[30,31]$. In a study developed in South Korean with 213 patients with COVID-19 confirmed, the median duration from the first symptom to RT-PCR confirmation was 14 days, 


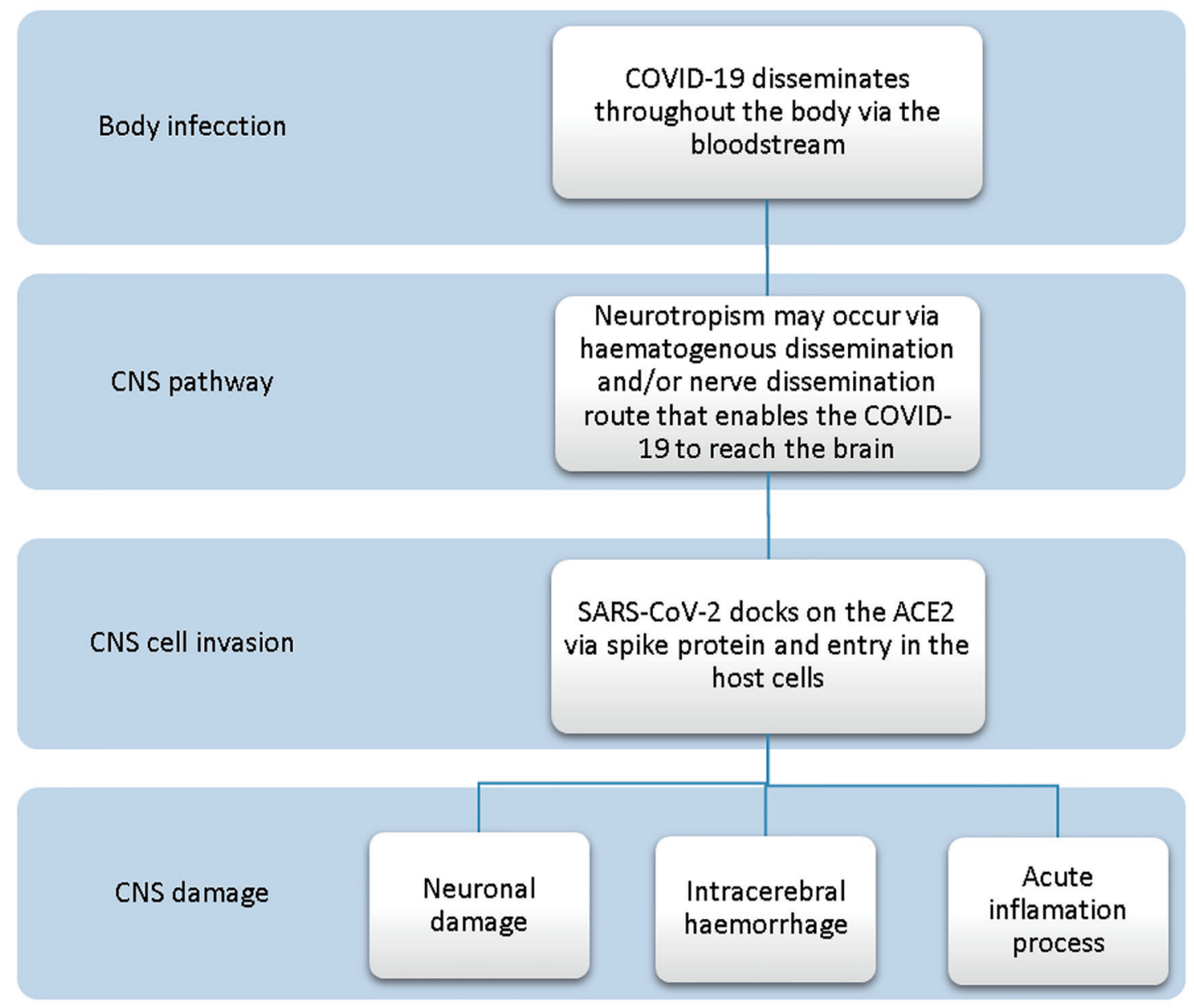

Figure 2. COVID-19 relationship with the nervous system.

and the median duration from RT-PCR confirmation to admission was 3 days [32]. This latency period can be enough for the virus to enter and destroy the medullary neurons [33]. In a retrospective study with 214 patients, the CNS manifestation was present in $25 \%$ of all patients and the main symptoms were dizziness (17\%), followed by headache (13\%) [17]. In a cohort study with 41 patients identified with laboratory-confirmed COVID-19, headache symptom was observed in $8 \%$ of the patients [2]. In other studies, headache varied between $6 \%$ and $8 \%$ of all patients that had been confirmed with COVID-19 [24-26].

The loss of smell and taste could be a nervous system manifestation but is not specific to COVID-19 because it commonly occurs in other viruses. Symptoms of anosmia and taste-related changes should be taken as an indication of SARS-CoV-2 infection [34]. In a cross-sectional study in Iran with 10,069 patients with hyposmia/anosmia, 7,608 patients (76\%) of them or their immediate families had upper respiratory symptoms [35]. It can suggest a possible correlation between the sudden increase in anosmia and the COVID-19 pandemic. In the same study, $83 \%$ of patients with anosmia also reported hypogeusia [35]. In Wuhan, China, a study with patients with peripheral nervous system symptoms showed that the most common complaints were hypogeusia (5.5\%) and hyposmia (5\%) of all patients [17]. Nervous system symptoms were significantly more common in severe cases as compared with non-severe cases, indicating as a poor prognostic factor [17].

The presence of SARS-CoV-2 in the cerebrospinal liquid has already been described in the literature and it is important to confirm the COVID-19 [36]. Thus, neuroinflammation pathology has been associated with COVID-19. Necrotizing encephalopathy and meningitis/encephalitis have been reported as a rare COVID-19 complication as such as in influenza infection and other viruses $[10,11]$. This pathological process should occur in a severe subgroup of patients with COVID-19 due to hyper-inflammatory syndrome $[10,11,36,37]$. In a COVID-19 patient with necrotizing encephalopathy, brain magnetic resonance imaging (MRI) showed hemorrhagic rim enhancing lesions within the bilateral thalami, medial temporal lobes and subinsular region [11]. Meningitis/encephalitis in COVID-19 patient was showed on diffusion-weighted MRI with hyperintensity along the wall of the inferior horn of the right lateral ventricle [10].

Another target of discussion is if SARS-CoV-2 CNS may be a cause of para-infectious neurological diseases such as Guillain-Barre syndrome (GBS) or acute disseminated encephalomyelitis as observed in the Zika virus infection [38]. 
GBS has also been reported in patients with COVID-19 [13-16]. Before the COVID-19 pandemic, only two cases of other $\mathrm{CoV}$ were reported in the literature with the GBS association. One of them was a man with MERS-CoV infection who developed Bickerstaff encephalitis, and another case was a 5 years old boy who developed an atypical GBS after a respiratory infection by HCoV-OC43 $[39,40]$. The physiopathology about this topic is not clear.

\section{COVID-19 and ischemic stroke}

COVID-19 may predispose to venous and arterial thromboembolic disease due to excessive inflammation, hypoxia and diffuse intravascular coagulation $[36,41]$. Thus, acute pulmonary embolism, deep-vein thrombosis, ischemic stroke, myocardial infarction, or systemic arterial embolism are possible COVID-19 manifestations [42].

In a study with 184 patients with proven COVID-19 pneumonia admitted to the intensive care unit, coagulopathy during admission was observed in $38 \%$ of the patients and ischemic stroke in $4 \%$ [42]. Mao et al observed $5.7 \%$ of the patients had developed the cerebrovascular disease in the course of COVID-19 severe infection [17]. In the study of Li et al with 221 patients, the incidence of cerebrovascular disease in COVID-19 patients was $6 \%$ and $84 \%$ of these patients had developed ischemic stroke [3].

The incidence of ischemic stroke was associated with a higher prevalence of risk factors such as diabetes, hypertension, coronary artery disease, malignancy disease and previous cerebrovascular disease [3, 4, 41, 42]. Elevation of D-dimer (over $3442 \mathrm{ng} / \mathrm{mL}$ ) and CRP (over $16.24 \mathrm{ng} / \mathrm{dL}$ ) also had an association with strokes in COVID-19 patients [42]. SARS-CoV-2 infection can increase the risk of stroke in 3.2 to 7.82 folds within the first 3 days after other respiratory tract infections [43, 44].

Average time durations from the first symptoms of SARSCoV-2 infection to the cerebrovascular event was 10 days [41]. In a case series with six patients, five patients developed ischemic stroke between 8 and 24 days after COVID-19 symptom onset [6].

The prevalent age to develop ischemic stroke is not clear. The prevalent age to developed acute stroke varied between 57 and 91 years in Li et al's study [3]. In a series of cases with four patients who developed ischemic stroke, the average age was 81 and the mortality rate was 75\% [4]. However, large-vessel stroke in patients younger than 50 years of age was observed by Oxley et al in their case series with five patients [8].

\section{Blood investigation}

The severe patients had higher D-dimer levels than non-severe patients and also had multiple organ involvement, such as serious liver, kidney and muscle damage [17]. Some studies have shown that patients with CNS symptoms had lower lymphocyte, platelet counts, and higher CRP and blood urea nitrogen levels compared with those without CNS symptoms [11, 17].

\section{CNS involvement in COVID-19 management}

The management of COVID-19 patients with CNS involvement is still not clear. The treatment for acute neuroinflammatory infection can be made with intravenous immunoglobulins as was reported in a case of necrotizing hemorrhagic encephalopathy [11]. In the treatment of meningitis/encephalitis, the use of antibiotics, antiviral and corticosteroids was reported [10], but the scientific evidence has been demonstrated that corticosteroid should not be used for the routine treatment of SARS-CoV-2 because of demonstrated poor prognosis in patients with lung injury or shock [45].

Currently, patients with ischemic stroke symptoms should be treated as suspected or possible COVID-19 patients [46]. Routine thromboprophylaxis is not recommended in ambulatory patients with acute medical illness or respiratory symptoms [18]. In the emergency room, patients diagnosed with ischemic stroke should receive the standard of stroke care and should be evaluated for potential thrombolysis with plasminogen activator or tenecteplase. Endovascular thrombectomy should be done when large vessel occlusion is suspected [46].

\section{Conclusion}

The impact of COVID-19 on the healthcare system makes urgent knowledge about appropriate diagnosis and treatment. Data from the current literature reveal that patients who suffer from a severe illness have more CNS involvement, neurological symptoms, and also had an association with strokes. The endothelial rupture in cerebral capillaries can bleed before neuronal damage happens. Precise studies and targeted documentation are still necessary to determine physiopathology, clinical manifestations, factor prognosis, diagnosis and treatment about this topic.

\section{Acknowledgments}

None to declare.

\section{Financial Disclosure}

None to declare.

\section{Conflict of Interest}

None to declare.

\section{Author Contributions}

Conceptualization: Pedro L. R. Aquino, Luiz S. B. Junior, Maria A. R. Aquino, Ana C. V. Silva, Nicollas N. Rabelo, Rita C. 
F. V. Mota. Project administration: Luiz S. B. Junior and Pedro L. R. Aquino. Formal analysis: Hildo R. C. Azevedo, Nicollas N. Rabelo, Ana C. V. Silva. Writing original draft: Pedro L. R. Aquino, Maria A. R. Aquino, Luiz S. B. Junior. Writing review and editing: Ana C. V. Silva, Nicollas N. Rabelo, Rita C. F. V. Mota, Hildo R. C. Azevedo.

\section{Data Availability}

The authors declare that data supporting the findings of this study are available within the article.

\section{References}

1. Cetinkaya EA. Coincidence of COVID-19 Infection and Smell: Taste Perception Disorders. J Craniofac Surg. 2020.

2. Huang C, Wang Y, Li X, Ren L, Zhao J, Hu Y, Zhang L, et al. Clinical features of patients infected with 2019 novel coronavirus in Wuhan, China. Lancet. 2020;395(10223):497506.

3. Li Y, Wang M, Zhou Y, Chang J, Xian Y, Mao L, et al. Acute cerebrovascular disease following COVID-19: a single center, retrospective, observational study. SSRN Electron J. 2020;19.

4. Avula A, Nalleballe K, Narula N, Sapozhnikov S, Dandu V, Toom S, et al. COVID-19 presenting as stroke. Brain, Behavior, and Immunity. 2020.

5. Al Saiegh F, Ghosh R, Leibold A, Avery MB, Schmidt RF, Theofanis T, Mouchtouris N, et al. Status of SARSCoV-2 in cerebrospinal fluid of patients with COVID-19 and stroke. J Neurol Neurosurg Psychiatry. 2020.

6. Beyrouti R, Adams ME, Benjamin L, Cohen H, Farmer SF, Goh YY, Humphries F, et al. Characteristics of ischaemic stroke associated with COVID-19. J Neurol Neurosurg Psychiatry. 2020.

7. Gonzalez-Pinto T, Luna-Rodriguez A, Moreno-Estebanez A, Agirre-Beitia G, Rodriguez-Antiguedad A, Ruiz-Lopez M. Emergency room neurology in times of COVID-19: malignant ischaemic stroke and SARS-CoV-2 infection. Eur J Neurol. 2020.

8. Oxley TJ, Mocco J, Majidi S, Kellner CP, Shoirah H, Singh IP, De Leacy RA, et al. Large-vessel stroke as a presenting feature of COVID-19 in the young. N Engl J Med. 2020;382(20):e60.

9. Moshayedi P, Ryan TE, Mejia LLP, Nour M, Liebeskind DS. Triage of acute ischemic stroke in confirmed COVID-19: large vessel occlusion associated with coronavirus infection. Front Neurol. 2020;11:353.

10. Moriguchi T, Harii N, Goto J, Harada D, Sugawara H, Takamino J, Ueno M, et al. A first case of meningitis/encephalitis associated with SARS-Coronavirus-2. Int J Infect Dis. 2020;94:55-58.

11. Poyiadji N, Shahin G, Noujaim D, Stone M, Patel S, Griffith B. COVID-19-associated acute hemorrhagic necrotizing encephalopathy: CT and MRI features. Radiology. 2020:201187.
12. Zanin L, Saraceno G, Panciani PP, Renisi G, Signorini L, Migliorati K, Fontanella MM. SARS-CoV-2 can induce brain and spine demyelinating lesions. Acta Neurochir (Wien). 2020;162(7):1491-1494.

13. Alberti P, Beretta S, Piatti M, Karantzoulis A, Piatti ML, Santoro P, Vigano M, et al. Guillain-Barre syndrome related to COVID-19 infection. Neurol Neuroimmunol Neuroinflamm. 2020;7(4).

14. Virani A, Rabold E, Hanson T, Haag A, Elrufay R, Cheema T, Balaan M, et al. Guillain-Barre Syndrome associated with SARS-CoV-2 infection. IDCases. 2020:e0771.

15. Sedaghat Z, Karimi N. Guillain Barre syndrome associated with COVID-19 infection: A case report. J Clin Neurosci. 2020;76:233-235.

16. Zhao H, Shen D, Zhou H, Liu J, Chen S. Guillain-Barre syndrome associated with SARS-CoV-2 infection: causality or coincidence? Lancet Neurol. 2020;19(5):383384.

17. Mao L, Jin H, Wang M, Hu Y, Chen S, He Q, Chang J, et al. Neurologic manifestations of hospitalized patients with coronavirus disease 2019 in Wuhan, China. JAMA Neurol. 2020.

18. Lodigiani C, Iapichino G, Carenzo L, Cecconi M, Ferrazzi $\mathrm{P}$, Sebastian $\mathrm{T}$, Kucher $\mathrm{N}$, et al. Venous and arterial thromboembolic complications in COVID-19 patients admitted to an academic hospital in Milan, Italy. Thromb Res. 2020;191:9-14.

19. Wu ZG, Zhao F, Yu S, Chen B, Wang YM, Hu W, et al. Severe acute respiratory syndrome coronavirus 2 isolate Wuhan-Hu1, co - Nucleotide-NCBI. Nature. 2020.

20. Mankad K, Perry MD, Mirsky DM, Rossi A. COVID-19: A primer for Neuroradiologists. Neuroradiology. 2020;62(6):647-648.

21. Netland J, Meyerholz DK, Moore S, Cassell M, Perlman S. Severe acute respiratory syndrome coronavirus infection causes neuronal death in the absence of encephalitis in mice transgenic for human ACE2. J Virol. 2008;82(15):7264-7275.

22. Wrapp D, Wang N, Corbett KS, Goldsmith JA, Hsieh CL, Abiona O, Graham BS, et al. Cryo-EM structure of the 2019-nCoV spike in the prefusion conformation. Science. 2020;367(6483):1260-1263.

23. Bohmwald K, Galvez NMS, Rios M, Kalergis AM. Neurologic alterations due to respiratory virus infections. Front Cell Neurosci. 2018;12:386.

24. Gu J, Gong E, Zhang B, Zheng J, Gao Z, Zhong Y, Zou $\mathrm{W}$, et al. Multiple organ infection and the pathogenesis of SARS. J Exp Med. 2005;202(3):415-424.

25. Roldan-Valadez E, Martinez-Anda JJ, Corona-Cedillo R. Imaging anatomy of the cranial nerves. Nerves Nerve Inj. 2015;1:173-193.

26. Dube M, Le Coupanec A, Wong AHM, Rini JM, Desforges M, Talbot PJ. Axonal transport enables neuron-toneuron propagation of human coronavirus OC43. J Virol. 2018;92(17).

27. Vaira LA, Deiana G, Fois AG, Pirina P, Madeddu G, De Vito A, Babudieri S, et al. Objective evaluation of anosmia and ageusia in COVID-19 patients: Single-center experience on 72 cases. Head Neck. 2020;42(6):1252-1258. 
28. Baig AM, Khaleeg A, Ali U, Syeda H. Evidence of the COVID-19 Virus Targeting the CNS: Tissue Distribution, Host-Virus Interaction, and Proposed Neurotropic Mechanisms. ACS Chem Neurosci. 2020;11(7):995-998.

29. Tirotta E, Duncker P, Oak J, Klaus S, Tsukamoto MR, Gov L, Lane TE. Epstein-Barr virus-induced gene 3 negatively regulates neuroinflammation and $\mathrm{T}$ cell activation following coronavirus-induced encephalomyelitis. J Neuroimmunol. 2013;254(1-2):110-116.

30. Wang D, Hu B, Hu C, Zhu F, Liu X, Zhang J, Wang B, et al. Clinical characteristics of 138 hospitalized patients with 2019 novel coronavirus-infected pneumonia in Wuhan, China. JAMA. 2020.

31. Chen N, Zhou M, Dong X, Qu J, Gong F, Han Y, Qiu Y, et al. Epidemiological and clinical characteristics of 99 cases of 2019 novel coronavirus pneumonia in Wuhan, China: a descriptive study. Lancet. 2020;395(10223):507513.

32. Kim GU, Kim MJ, Ra SH, Lee J, Bae S, Jung J, Kim SH. Clinical characteristics of asymptomatic and symptomatic patients with mild COVID-19. Clin Microbiol Infect. 2020.

33. Baig AM. Updates on What ACS Reported: Emerging Evidences of COVID-19 with Nervous System Involvement. ACS Chem Neurosci. 2020;11(9):1204-1205.

34. COVID-19 anosmia reporting tool. American Academy of Otolaryngology-Head and Neck Surgery. https://www. entnet.org/content/reporting-tool-patients-anosmia-related-covid19. 2020.

35. Karimi-Galougahi M, Raad N, Mikaniki N. Anosmia and the Need for COVID-19 Screening during the Pandemic. Otolaryngol Head Neck Surg. 2020:194599820925056.

36. Wu Y, Xu X, Chen Z, Duan J , Hashimoto K, Yang L, Liu C, et al. Nervous system involvement after infection with COVID-19 and other coronaviruses. Brain Behav Immun. 2020;87:18-22.

37. Krzysztof NJ, Christoffer LJ, Rahul K, Ricanek P, Jonas
H, Jack S. Age, inflammation and disease location are critical determinants of intestinal expression of SARSCoV-2 receptor ACE2 and TMPRSS2 in inflammatory bowel disease. Gastroenterology. 2020.

38. Carod-Artal FJ. Neurological complications of coronavirus and COVID-19. Rev Neurol. 2020;70(9):311-322.

39. Kim JE, Heo JH, Kim HO, Song SH, Park SS, Park TH, Ahn JY, et al. Neurological Complications during Treatment of Middle East Respiratory Syndrome. J Clin Neurol. 2017;13(3):227-233.

40. Sharma K, Tengsupakul S, Sanchez O, Phaltas R, Maertens P. Guillain-Barre syndrome with unilateral peripheral facial and bulbar palsy in a child: A case report. SAGE Open Med Case Rep. 2019;7:2050313X19838750.

41. Zhou F, Yu T, Du R, Fan G, Liu Y, Liu Z, Xiang J, et al. Clinical course and risk factors for mortality of adult inpatients with COVID-19 in Wuhan, China: a retrospective cohort study. Lancet. 2020;395(10229):1054-1062.

42. Klok FA, Kruip M, van der Meer NJM, Arbous MS, Gommers D, Kant KM, Kaptein FHJ, et al. Incidence of thrombotic complications in critically ill ICU patients with COVID-19. Thromb Res. 2020;191:145-147.

43. Smeeth L, Thomas SL, Hall AJ, Hubbard R, Farrington P, Vallance P. Risk of myocardial infarction and stroke after acute infection or vaccination. N Engl J Med. 2004;351(25):2611-2618

44. Warren-Gash C, Blackburn R, Whitaker H, McMenamin J, Hayward AC. Laboratory-confirmed respiratory infections as triggers for acute myocardial infarction and stroke: a self-controlled case series analysis of national linked datasets from Scotland. Eur Respir J. 2018;51(3).

45. Russell CD, Millar JE, Baillie JK. Clinical evidence does not support corticosteroid treatment for 2019-nCoV lung injury. Lancet. 2020;395(10223):473-475.

46. Dafer RM, Osteraas ND, Biller J. Acute stroke care in the coronavirus disease 2019 pandemic. J Stroke Cerebrovasc Dis. 2020;29(7):104881. 